\title{
Building a Global Bookshelf: In Recognition of the United Nations Literacy Decade 2003-2012
}

\author{
Louise Boyle Swiniarski
}

Published online: 25 September 2011

(C) Springer Science+Business Media, LLC 2011

\begin{abstract}
This guest editorial promotes the United Nations Literacy Decade of 2003-2012 as it is implemented in preschools and primary schools to develop global literacy competencies in young children through a project entitled, Building a Global Bookshelf.
\end{abstract}

Keywords United Nations · Global literacy · Advocacy · Young children $\cdot$ International campaign

The United Nations Literacy Decade (UNLD) was established to answer the call of the United Nations' Education for All mandate. Since literacy skills are basic to an education that empowers world citizens as participating members of society, the United Nations General Assembly charged UNESCO with the mission of promoting literacy skills for adults as well as children around the world. Literacy, defined as a "human right" under the UN Convention of Human Rights and UN Convention for the Rights of the Child, is the cornerstone for this UNESCO directive (www.unesco.org). The organization's intent is to support all developing and developed nations with low literacy rates, inadequate reading abilities, and limited educational opportunities in reaching their literacy goals as well as to promote sensitivity in all global citizens, children and adults, to the need for literacy. Global literacy has multifaceted meanings, including literal language and reading skills along with cultural, racial, and national sensitivities to human rights.

The goals have been set high to master functional levels of literacy skills that can combine with other basic

L. B. Swiniarski ( $₫)$

Salem State University, Salem, MA, USA

e-mail: 1swiniarski@salemstate.edu competencies to sustain a dynamic literate environment for all adults and children in the twenty-first century (www. unesco.org). The tasks at hand are to move literacy teaching beyond the emergent reading and writing levels. The objectives are to attain reading comprehension skills, critical thinking, and articulate expression. The ultimate aim is to enable people everywhere to voice fluently their beliefs and their concerns with equal opportunities in an equitable world.

The UNLD is a campaign to counter earlier efforts of promoting global literacy. The statistics for illiteracy have not as yet changed in the twenty-first century. Globally "one in five adults can't read nor write [while] approximately 776 million people are illiterate and two-thirds of these are women" (www.unesco.org). A decade of effort is aimed at turning around those findings by avoiding previously used twentieth century "silver bullet" approaches. Sustainable programs, innovative on-going projects, and informative activities are to replace earlier failed attempts at addressing the insurmountable problems of providing effective literacy instruction globally (www.unesco.org).

The Building a Global Bookshelf Project is a global educational initiative that was developed to meet the UN challenge and celebrate the UNLD's mission. The Northeast Global Education Center at Salem State University (NGEC) ${ }^{1}$ introduced the Global Bookshelf project to the schools of Massachusetts as a model program aimed at promoting global literacy skills in young children, aged three to nine. Based on the UNLD's motto, Literacy for All, the program intends to bring its message to all children in Massachusetts, including children who have recently emigrated from nations around the world; English Language Learners, as well as native born children. NGEC sponsors the project as a school

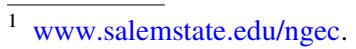


based professional development opportunity for teachers, a storytelling experience for children, and a family literacy program for home. Several storytellers and readers visit the schools along with a member from the center to work together with literature that reflects a global outlook. A story can be told from various perspectives, when it is traced from its land of origins and read in another language or with an array of regional dialects. Readers retell tales from international collections of authors, share books illustrated by local globally acclaimed artists, and read works created by the children themselves. A global bookshelf is built in each classroom to house the volumes of books left after each school visit. Follow up activities enhance the readings and extend meanings and vocabulary. Older children are encouraged to voice their own stories. They adapt classical works to local or contemporary settings. They create their own narratives and poems which they publish and display along-side works of professional authors in a Global Bookshelf designed by classmates. The Global Bookshelf invites all children to revisit a story from the bookcase in their classroom or to take home from it a favorite book to share with family members.

Based on early childhood pedagogy, the project extends literacy activities to include transformative teaching practices for global awareness and cultural sensitivity in the daily reading and writing experiences of preschool and primary school aged children (Rankin et al. 2008). Literacy skills are spiraled at each grade level through the introduction of international books that offer different origins and points of view. Global education themes infuse and integrate literacy skills with competencies across the curriculum. The themes include: Unity and Diversity in World Citizenship, Movement of Ideas across the Globe, Forming International Partnerships, Local Partners Bridge Global Connections, Art Forms Are International Languages, and Global Perspectives Produce Critical Thinkers. Themes continue to be added as the project progresses.

In selecting books, NGEC has been careful to include a variety of literary forms from the cultural heritage of the children being served as well as cultures not represented in the audiences or book collections of the participating schools. Books are added to the shelf that offer a balance of heroes and heroines from all corners of the world along with books translated in many languages or the original language of a tale. Recommendations for books come from various sources and an interdisciplinary/international group of colleagues. They include authors and illustrators of original works, museum curators and librarians, international visitors, teachers, community booksellers, family members, and the children themselves. Efforts are made to collaborate with teachers in choosing topics and stories in ways that align the project with the schools' curricula. The initial presentations should begin with some favorite tales of the children, so surveys of their preferences are made and honored. The International Children's Digital Library is a valuable resource for identifying books that are culturally sensitive and avoid the stereotypes often found in children's literature (www.icdlbooks.org).

While some outcomes are evident, assessments of the Global Bookshelf Project are on-going. Much of the data gathering to date is anecdotal. Individual groups of children have been followed at various schools sites for one year at a time, while at other school sites, children have been observed over a period of three years. The school districts are both urban and suburban. Individual school populations differ in socio-economic, racial, cultural, and linguistic backgrounds, so care is taken to present a story in context of the children's place in the world to demonstrate that the world is not "out there" but begins with them and their community, a basic principle of teaching global education, (Swiniarski and Breitborde 2003). Thus, children, preschool and primary school ages, were able to make connections between their communities and communities elsewhere. In all instances, the children evidence an emerging sensitivity to cultural differences and pride of one's own heritage. Follow up experiences show an increased interest in people from other places in the world.

Reading many interpretations of the same folktale helped the children verbalize their perceptions and acceptance of differing points of views - a daunting task for preschoolers and kindergartners who are often ego-centric in their thinking. Kindergartners were able to follow how ideas in books move from place to place around the globe, changing and adapting to each new environment but retaining the same story lines. Creative and critical thinking skills of first graders were apparent in their published books and in the analysis of stories they depicted in illustrations. The preschoolers were adept at their renditions of stories with puppets and felt board characters re-enactments, particularly when they used the enhanced vocabulary of the storytelling sessions. Third graders were excited they could write the same word with correct American and British spellings. Having eight year olds enthusiastic about spelling was refreshing! Second graders shared their favorite global bookshelf stories, told to them in previous years, yet recalled by each child in detail. The data gathering is incomplete and ongoing. As the children proceed through the upper grades, a critical study in later years will assess the longitudinal success. Present results are positive and resonate with the goals of the UNLD.

The implications of the project are far reaching. While the decade is soon ending in 2012, the UNLD mission continues. In response to the United Nations' slogan of "Literacy as Freedom" (www.unesco.org), NGEC has been persistent in publicizing the purpose of the project. The Global Bookshelf Project was shared with 
international professionals in the fields of education, informational technology, library sciences, and peace education curriculum development at conferences held in America, Canada, England, Northern Ireland, and Belgium. NGEC is reaching its tenth year with the project and still advocating for new avenues to accomplish the UNLD mission. The current proposal is to expand the Global Bookshelf Project with a family literacy component. The plan is to fund and distribute additional copies of books for each child to place in a family Global Bookshelf at home. Cooperative efforts are being pursued in this aspiration to reach more adults within families. To date, community volunteers, social agencies, public and school librarians are assisting in developing this family literacy module. The
Building a Global Bookshelf Project is a rally call for a variety of constituents to join in the campaign, Literacy for All. You are most welcome to come on board.

\section{References}

Rankin, C., Swiniarski, L., \& Brock, A. (2008). Promoting education for the global village: The global bookshelf for children: In: Proceedings of the international peace research association 2008 conference at the University of Leuven, Belgium.

Swiniarski, L., \& Breitborde, M. (2003). Educating the global village: Including the child in the world. Columbus, Ohio: Pearson, Prentice-Hall. 